\title{
EFFECTS OF GLYCINE BETAINE CONCENTRATIONS ON THE AGRONOMIC CHARACTERISTICS OF STRAWBERRY GROWN UNDER DEFICIT IRRIGATION CONDITIONS
}

\author{
ADAK, N. \\ Akdeniz University, Faculty of Agriculture, Department of Horticulture, 07058 Antalya, Turkey \\ (e-mail: nafiyeadak@gmail.com; phone: +90-242-3102469; fax: +90-242-2274564) \\ (Received 29 $9^{\text {th }}$ Dec 2018; accepted $14^{\text {th }}$ Feb 2019)
}

\begin{abstract}
Glycine betaine (GB) is a quaternary ammonium compound that can be found in a wide range of bacterial, plant and animal species. The exogenous application of GB is a convenient method for the induction of crop tolerance to various abiotic stresses. We examined the effects of different exogenous GB concentrations to deficit irrigation conditions (15\% drainage) under soilless condition in terms of morpho-physiological, yield, quality and biochemical features. The different GB concentrations $(0,10$ and $20 \mathrm{mM}$ ) were used in Fortuna and Albion strawberry cultivars. As a result of the research, GB treatments increased plant growth and yield under deficit irrigation conditions. Fruit weight inclined by $26.29-49.50 \%$ and fruit yield by $17.17-39.59 \%$ at GB treatments as compared to control. Regarding biochemical content, increasing GB concentrations from $0 \mathrm{mM}$ to $20 \mathrm{mM}$ caused total anthocyanin to decrease, whereas the ascorbic acid increased. Furthermore, the highest yield, fruit firmness, chroma and total anthocyanin were determined in the Fortuna; the highest total soluble solid and ascorbic acid content in the Albion cultivar. Our results showed that the increase in yield and quality was due to exogenous GB applications. Indeed, water stress tolerance varied depending on cultivars.
\end{abstract}

Keywords: water stress, ascorbic acid, colour, total anthocyanins, yield

\section{Introduction}

Many strategies aimed at saving water are practiced in horticulture (Tunc et al., 2019). Drip irrigation method increases the efficiency of water use while decreasing the applied amount (Tunc et al., 2019). Mulch usage is a very important cultural practice to decrease evapotranspiration in conventional agriculture. Recent years, soilless culture techniques have expanded to increase the efficiency of water use in many agriculture countries. In addition, soilless culture enables lower water usage, lower fertilizer and higher yield per unit area than conventional method. Therefore this technique is known as a sustainable agricultural method. In fact, in Turkey, while 390 tons of water/decare is used under soil conditions with clay soil in the Mediterrenean region, in soilless systems much less water is used.

Turkey, with a strawberry production of 415150 tons in a production area of 15431 ha, was ranked fifth in 2016 in global production according to the FAOSTAT statistics (FAO, 2018). The strawberry protected production quantity increased by $40.51 \%$ (168,191 tons) in total production (TURKSTAT, 2017). Under protected conditions, there is a remarkable increase in general soilless production areas and the total soilless strawberry production area has reached 70 ha (Adak et al., 2018a). In soilless cultivation about 1.5-2 L of growing media/plant is used and even short time water stress causes loss of turgor (Adak, 2009). Thus, abiotic stress experiments, for example water stress, salinity stress, are conducted easier, faster in soilless culture technique as compared to conventional agriculture technique.

Recently, the most important environmental and agricultural problems are global warming and water shortage (Cramer et al., 2007; Fereres and Soriano, 2007; Osakabe 
et al., 2014; Bakhsh and Hussain, 2015; Zhu, 2016). In particular, salinity and drought are two major constraints that limit agricultural production worldwide. Mainly drought stress causes to decrease yield and quality and affects biochemical features in arid or semi-arid climate, for example Mediterrenean conditions (Souza et al., 2004; Zlatev and Lidon, 2012; Adak et al., 2018b; Tunc et al., 2019). Adak et al. (2018b) stated that some of the fruit's physical features were affected negatively by stress conditions whereas many of the biochemical features such as total anthocyanin content, total phenolic content and antioxidant activity were positively modulated in strawberries. Barreales et al. (2019) stated that deficit irrigation applications drastically affect the phytochemical composition and antioxidant activity of grapevine leaves. Controversaly, Centofanti et al. (2017) indicated that the deficit irrigation strategies did not affect the yield, fruit color, $\mathrm{pH}$, concentration of soluble solids, total phenolic compounds, anthocyanin and non- anthocyanin compounds, and mineral elements in pomegranate fruit.

Plants have evolved various protective mechanisms that allow them to acclimate to unfavourable environments for continued survival and growth (Wani et al., 2013). Osmotic adjustment is an adaptive mechanism involved in drought or salinity tolerance, which permits the maintenance of turgor under water deficit conditions (Wani et al., 2013). Different strategies have been improved for management of these stresses (Wani et al., 2013). Recently, some exogenous agent applications, such as aminoacids, plant nutrients, hormone-like compounds, have been tried in terms of practical usage for producer (Ahmad et al., 2007; Shi et al., 2014; Osman and Salim, 2016). In this regard, osmoprotectants or compatible solutes are small molecules that act as osmolytes and help organisms survive extreme osmotic stress (Lang, 2007).

Glycine betaine, an amino acid derivate from sugar beet (Beta Vulgaris L. v. altissima), is purified, enriched and crystallised (Makela et al., 1998; Rajashekar et al., 1999). The known role of GB is maintaining water content in plant cells by lowering solute potential under osmotic stress in osmotic adjustment (Makela, 2004; Dutta et al., 2018). Both the exogenous application of GB and the genetically engineered biosynthesis of GB in such crops is a promising strategy to increase stress tolerance (Wani et al., 2013). As a matter of fact, it ameliorated the harmful effects to various abiotic stress conditions, such as drought (Makela et al., 1998; Rajashekar et al., 1999; Rezaei et al., 2012; Zamani et al., 2014; Dawood, 2016; Rady et al., 2018), high salinity (YingYun et al., 2012; Yildirim et al., 2015), low temperature (Rajashekar et al., 1999; Zhang et al., 2008) and heat stresses (Oukarroum et al., 2012) in many crops. In addition, exogenous application of GB in non-accumulator plants may be a possible alternative approach for tolerance improvement against multiple abiotic stresses (Harinasut et al., 1996; Diaz-Zorita et al., 2001; Yang and Lu, 2005). In fact, tomato plants (Lycopersicon esculentum Mill.) do not naturally accumulate GB (Wyn Jones and Storey, 1981). However, Park et al. (2006) stated that exogenous application of glycine betaine increases chilling tolerance in tomato plants.

Glycine betaine can be phytotoxic, when applied either at higher concentration or by increasing the number of applications. The species such as bean, tomato, and grape are more sensitive to high concentrations of GB than grass species/cereals. Therefore, it is important to determine optimal concentration of GB, number of applications, and time of application for each crop species (Muhammad et al., 2006). In this regard, Rajashekar et al. (1999) determined exogenous application of glycine betaine (2 mM) to strawberry plants increased the cold tolerance of leaves within $72 \mathrm{~h}$ of application. Likewise, Armin and Reza Miri (2014) examined different application types of glycine betaine 
(seed-treating, seed-treating+foliage spraying, spraying at flowering and nonapplication of glycine betaine) under rain-fed and irrigated conditions. $100 \mathrm{mM} \mathrm{GB}$ concentration was used in both seed treating and spraying. The result of this study, the seed application+spraying of glycine betaine was superior to other application methods in terms of yield and yield components increasing in cumin plants. Yildirim et al. (2015) observed that exogenous GB treatments at 10 and $25 \mathrm{mmol}^{-1} \mathrm{l}^{-1}$ elevated the concentrations of gibberellic acid, salicylic acid and indole acetic acid levels and it could ameliorate the harmful effects of salt stress in lettuce. Shams et al. (2016) suggested that exogenous GB treatments could ameliorate the tolerance of lettuce to salt stress by increasing the total antioxidants and total phenolics. Likewise, Youssef et al. (2018) foliar GB at $10 \mathrm{mM}$ to cucumber plants ameliorated the harmful effects of $\mathrm{NaCl}$ stress on the vegetative growth and yield through enhancing both leaf relative water content and leaf membrane stability. In additon, Denaxa et al. (2012) stated GB and kaolin clay particles treatments increased $\mathrm{CO}_{2}$ assimilation rates drought stress as compared to control in olive (Olea europaea L.) plants.

In this regard, a little is known about the effects of exogenously applied glycinebetaine concentrations on quantitative and qualititative characteristics in different strawberry cultivars and deficit irrigation conditions with soilless cultivation. As a matter of fact, in strawberries, the degree of water stress tolerance varies according to plant growth stage, stress duration, growing system, growing medium and cultivars (Adak et al., 2018b). Therefore, optimal GB concentrations and number of application and time of application should be determined in strawberry as well. The aim of the study were to assess the effectiveness of GB concentrations in different strawberry cultivars in terms of morphophysiological, yield, quality and biochemical characteristics. Thus, the most suitable GB concentrations will be determined for drought conditions and it will be recommended to producers working under water stress conditions.

\section{Materials and Methods}

\section{Plant Materials, Growing Conditions and Treatments}

Experiments were conducted between October 2015-February 2016 in high plastic greenhouse owned by the private research center located in Serik-Antalya (36 $50^{\prime} 37^{\prime \prime}$ $\mathrm{N} ; 30^{\circ} 50^{\prime} 31^{\prime \prime} \mathrm{E}$; at an altitude of $50 \mathrm{~m}$ ). Climatic data during the experiment are given in Table 1.

Table 1. Monthly averages of temperature $\left({ }^{\circ} \mathrm{C}\right)$ and relative humidity (\%) inside the experimental greenhouse

\begin{tabular}{c|c|c|c|c|c}
\hline & October & November & December & January & February \\
\hline Temperature $\left({ }^{\circ} \mathbf{C}\right)$ & 25.9 & 22.5 & 17.9 & 16.8 & 18.2 \\
Relative humidity $(\%)$ & 72.23 & 68.54 & 69.65 & 65.30 & 69.30 \\
\hline
\end{tabular}

Treatments consisted of two strawberry cultivars (Fortuna and Albion) and three glycine betaine concentrations with control (0, 10 and $20 \mathrm{mM} \mathrm{GB})$ under deficit irrigation condition (15\% dranaige fraction). Seedlings were planted in grow bags containing cocopeat $(100 \mathrm{~cm}$ in length $\times 15 \mathrm{~cm}$ in width $\times 7 \mathrm{~cm}$ in height) on the gutter at the height of $75 \mathrm{~cm}$ on 20 October $2015\left(14.2\right.$ seedlings $\left.\cdot \mathrm{m}^{-2}\right)$. A control irrigation regime (30\% drainage) was applied to the plant for the first 2 weeks. Later, deficit 
irrigation (DI) regime (15\% dranaige) was followed from 03 November 2015 to 05 February 2016. In the system, a separate irrigation programme was implemented by using separate irrigation valves. Three different concentrations $(0,10,20 \mathrm{mM})$ of glycine betaine (GB) (Sigma-Aldrich, 98\%). were applied twice (during planting and 30 days after planting) through spraying the foliar part of plants. Ionized pure water was used in control treatment (0 mM GB).

The nutrient concentrations in the nutrient solution named as Starter Solution (from October to December) were in all treatments as follows: $4.50 \mathrm{mM} \mathrm{K}^{+}, 4.00 \mathrm{mM} \mathrm{Ca}^{2+}$, $1.25 \mathrm{mM} \mathrm{Mg}^{2+}, 0.50 \mathrm{mM} \mathrm{NH}_{4}{ }^{+}, 11.50 \mathrm{mM} \mathrm{NO}_{3}{ }^{-}, 1.00 \mathrm{mM} \mathrm{H}_{2} \mathrm{PO}_{4}{ }^{-}, 1.50 \mathrm{mM} \mathrm{SO}_{4}{ }^{2-}$, $20 \mu \mathrm{M}$ Fe, $10.0 \mu \mathrm{M} \mathrm{Mn}, 7.0 \mu \mathrm{M} \mathrm{Zn}, 0.75 \mu \mathrm{M} \mathrm{Cu}, 25.0 \mu \mathrm{M} \mathrm{B}$, and $0.50 \mu \mathrm{M}$ Mo. The $\mathrm{EC}$ and $\mathrm{pH}$ in the above NS were $1.55 \mathrm{dS} \cdot \mathrm{m}^{-1}$ and 5.6, respectively. On reproductive stage, fertigation solution was replenished with different nutrient concentrations than in the initial nutrient solution. In this stage, the ion concentrations in the reproductive solution applied (from December to February) in all treatments were as follows: 5.50 $\mathrm{mM} \mathrm{K}^{+}, 3.50 \mathrm{mM} \mathrm{Ca}^{2+}, 1.50 \mathrm{mM} \mathrm{Mg}^{2+}, 11.00 \mathrm{mM} \mathrm{NO}_{3}^{-}, 1.50 \mathrm{mM} \mathrm{H}_{2} \mathrm{PO}_{4}^{-}, 1.50 \mathrm{mM}$ $\mathrm{SO}_{4}{ }^{2-}, 20 \mu \mathrm{M} \mathrm{Fe}, 10.0 \mu \mathrm{M} \mathrm{Mn}, 7.0 \mu \mathrm{M} \mathrm{Zn}, 0.75 \mu \mathrm{M} \mathrm{Cu}, 25.0 \mu \mathrm{M} \mathrm{B}$, and $0.50 \mu \mathrm{M}$ Mo. The EC and $\mathrm{pH}$ in the above NS were $1.70 \mathrm{dS} \cdot \mathrm{m}^{-1}$ and 5.6 , respectively. In the experiment, irrigation schedule was programmed depending on solar radition (3-8 irrigation/day with $3 \mathrm{~min} /$ irrigation) and irrigation programmes were done by automatic fertilising system (INTA Crop Technology S.L, Murcia, Spain).

\section{Data Collection and Statistical Analysis}

In the experiment, the morpho-physiological features of plants (crown diameter, chlorophyll index), pomological features in fruits (fruit weight, total soluble solid, titratable acid, firmness, colour) and biochemical features (ascorbic acid, total monometric anthocyanin) were examined. While morpho-physiological observations were carried out from November to February, all pomological and biochemical analysis were done from samples taken at the end of January. The yield per plant was determined from the total yield values obtained during the whole season.

\section{Determination of crown diameter and chlorophyll index}

In plants, crown diameter and chlorophyll indexes were measured monthly with digital calipers, and with chlorophyll meter (Field Scoot CM1000), respectively. Results were expressed as average monthly taken datas from November to February.

\section{Determination of fruit weight and yield}

Fruit weight and fruit yield were determined throughout the growing season (2 December 2015 to 05 February 2016). Fruit weight was presented as grams (g), and yield as yield per plant.

\section{Determination of total soluble solids, titratable acidity and firmness}

Total soluble solids content (TSS) were measured by a digital refractometer (REF121; Atago, Guangzhou, China) and expressed as \%. The titratable acidity (TA) was determined by juice titration with $0.1 \mathrm{~N} \mathrm{NaOH}$ up to $8.1 \mathrm{pH}$ and expressed in $\%$ of citric acid per $100 \mathrm{~mL}$ juice (AOAC 1980). Firmness was determined by the equatorial region of fruit, using a texture analyser (FT-011, with $7 \mathrm{~mm}$ probe, Effegi, Italy) and expressed as $\mathrm{kg} \cdot \mathrm{cm}^{-2}$. 


\section{Colour measurements}

Fruit skin colour were measured by a Minolta CR-200 (MINOLTA Camera Co, LTD Ramsey, NJ) chromameter in terms of $\mathrm{L}^{*}$ (whiteness $=$ darkness), $\mathrm{a}^{*}$ (redness) and $b^{*}$ (yellowness) values. Hue angle (colour shade) was calculated from $\operatorname{arc} \tan \left(b^{*} / a^{*}\right)$ and chroma (colour saturation) was from square root $\left(\mathrm{a}^{* 2}+\mathrm{b}^{* 2}\right)$. High values of hue angle indicate more red-orange and low values more red-bluish colour. Chroma shows transition from grey (low values) to pure colour (high values) (Selcuk and Erkan, 2005).

\section{Determination of ascorbic acid (AA) and total monomeric anthocyanins (TMA)}

Ascorbic acid (AA) content of strawberry samples was analyzed according to Bozan et al. (1996) with HPLC method. Results were expressed as $\mathrm{mg} / 100 \mathrm{~g}$ fresh weight basis (FW). Total monomeric anthocyanins (TMA) were determined by the $\mathrm{pH}$-differential method. After $30 \mathrm{~min}$ incubation at room temperature extracts were diluted with buffers ( $\mathrm{pH} 1$ or 4.5), the absorbance was measured at 520 and $700 \mathrm{~nm}$ (Agilent 8453 spectrophotometer, Agilent Technologies). The anthocyanins were quantified as mg Pg-3 glk/kg fresh weight (FW) basis (Giusti and Wrolstad, 2001).

\section{Statistical analysis}

The treatments were arranged in randomised block design (RBD) using a $2 \times 3$ factorial arrangement with three replications and 26 plants per treatment. The data were analysed using the Statistical Analysis System software programme, version 9.0 (SAS Institute, Cary, NC, USA) by ANOVA and treatment means were statistically compared using LSD test $5 \%$ of error probability.

\section{Results and Discussion}

\section{Crown diameter and chlorophyll index}

The determined data on crown diameter and chlorophyll index are given in Table 2. As can be seen in Table 2, the effects of the GB concentrations, cultivar and GB concentrations $\mathrm{x}$ cultivar interactions on crown diameter were found to be statistically insignificant. Crown diameter values, depending on the treatments, ranged from $2.30 \mathrm{~mm}$ to $2.58 \mathrm{~mm}$.

In the case of chlorophyll index, there were statistical differences among the GB treatments and the highest chlorophyll index was observed at $10 \mathrm{mM}$ GB concentrations (341.83). In the experiment, while cultivars insignificantly influenced the chlorophyll index, interactions were determined to be significant (Table 2). As a matter of fact, the highest chlorophyll index was indicated at $10 \mathrm{mM}$ GB concentration x Albion cultivar interaction (346.00), while the lowest was at $20 \mathrm{mM} \mathrm{GB} \times$ Fortuna cultivar interaction (254.33) (Table 2).

Consequently, according to our results, $10 \mathrm{mM}$ GB concentration was the best concentration determined in terms of chlorophlly index. As for crown diameter, although statistical differences are insignificant, the highest values were founded at $10 \mathrm{mM}$ application. In this concern, no literature was found regarding the effect of different exogenous glycine betaine concentrations under deficit irrigation conditions on morpho-physiological features in soilless strawberry cultivation. However, regarding cold stress conditions, Aras and Esitken (2013) stated that GB applications in strawberries affected leaf-relative water content, chlorophyll index, membrane 
permeability criteria. In addition, the same researchers have also reported that concentration of $10 \mathrm{~g} / \mathrm{L} \mathrm{GB}$ has a protective effect on strawberries under cold stress. Likewise, Rajashejar et al. (1999) determined that exogenous application of glycine betaine $(2 \mathrm{mM})$ to strawberry plants increased the cold tolerance of leaves within $72 \mathrm{~h}$ of application.

Table 2. Effects of different glycine betaine concentrations on crown diameter and chlorophyll index at different strawberry cultivars grown under deficit irrigations

\begin{tabular}{|c|c|c|c|}
\hline \multirow{2}{*}{ Glycine Betaine Con. (mM) } & \multicolumn{2}{|c|}{ Cultivars } & \multirow{3}{*}{ Treatments } \\
\hline & Fortuna & Albion & \\
\hline \multicolumn{3}{|c|}{ Crown diameter (mm) } & \\
\hline 0 & 2.43 & 2.34 & 2.39 \\
\hline 10 & 2.58 & 2.42 & 2.50 \\
\hline 20 & 2.39 & 2.30 & 2.34 \\
\hline Cultivars & 2.47 & 2.36 & \\
\hline \multicolumn{4}{|c|}{ LSD $\% 5$ treatment:NS; LSD $\% 5$ cultivar: NS; LSD $\% 5$ treatmentx cultivar:NS } \\
\hline \multicolumn{4}{|c|}{ Chlorophyll index } \\
\hline 0 & $294.00 \mathrm{BC}^{*}$ & $294.33 \mathrm{AB}$ & $294.17 b^{*}$ \\
\hline 10 & $337.67 \mathrm{AB}$ & $346.00 \mathrm{~A}$ & 341.83 a \\
\hline 20 & $254.33 \mathrm{C}$ & $313.33 \mathrm{AB}$ & $283.83 \mathrm{~b}$ \\
\hline Cultivars & 295.33 & 317.89 & \\
\hline
\end{tabular}

*The comparison of the means of the cultivars is done within the same row and means of treatment in the same column and the interaction between all the values are significantly different $(P \leq 0.05)$ using LSD comparison test. The mean of treatment and cultivar are shown in lowercase letters while interactions are in uppercase.

** $n=26$

Other experiments examining different abiotic stress conditions and species indicated similar results. As a matter of fact, Mickelbart et al. (2006) stated application of GB (50, $100,200 \mathrm{mM}$ ) increased the average number of days to maximum leaf area, and specific leaf weight on grapevine. However, leaf water potential and leaf relative water content were unaffected by GB. In addition, while 100 or $200 \mathrm{mM}$ GB concentrations were determined as toxic concentrations, the research studies recommend concentrations below $50 \mathrm{mM}$ for further applications to increase stress tolerance of grapevine. Rezaei et al. (2012) investigated effects of exogenous GB concentrations $(0,5$ and $10 \mathrm{mM})$ in three stages with 10 days interval on some morpho-physiological characteristics of tomato plants at different levels of drought stress (weekly, bi-weekly and tri-weekly watering). Results showed vegetative growth parameters inclined as compared to control, that is shoot height by $70 \%$, root length by $73 \%$, leaf number by $187 \%$, leaf area by $193 \%$, total shoot fresh weight by $168 \%$, total shoot dry weight by $9 \%$, relative water content by $72 \%$ and stress tolerance index by $122 \%$. Zamani et al. (20131) examined effects of proline $(10 \mathrm{mM})$ and $\mathrm{GB}(15 \mathrm{mM})$ were sprayed on the grapevines at four growth stages (before flowering, flowering, sour cluster and veraison) under drought stress. Results showed that GB significantly affected leaf relative water content, canopy temperature, chlorophyll content, leaf area in all the treated cultivars. Shams et al. (2016) examined four concentrations of $\mathrm{GB}(0,5,10$, and $25 \mathrm{mM})$ and two levels of salinity $(0$ and $100 \mathrm{mM}$ of $\mathrm{NaCl})$ in lettuce plants. Results showed the $25 \mathrm{mM}$ GB treatment increased the dry matter by $44 \%$ as compared to control. Youssef et al. (2018) applied foliar GB at $10 \mathrm{mM}$ to cucumber plants which improved both chlorophyll 
contents and nutrient content under salt stress condition. Similarly, YingYun et al. (2012) reported that exogenous betaine significantly increased the photosynthetic pigments. Likewise, Rady et al. (2018) investigated the effects of different GB concentrations $(0,25$ and $50 \mathrm{mM})$ under $4.80 \mathrm{dS} \mathrm{m}^{-1}$ salt stress on onion. GB treatment significantly increased shoot length, leaves area of plant, shoot fresh and dry weights, bulb yields, leaf chlorophyll contents, leaf relative water content and membrane stability index. Research studies determined that a level of $50 \mathrm{mM} \mathrm{GB}$ was more effective under moderate salt stress.

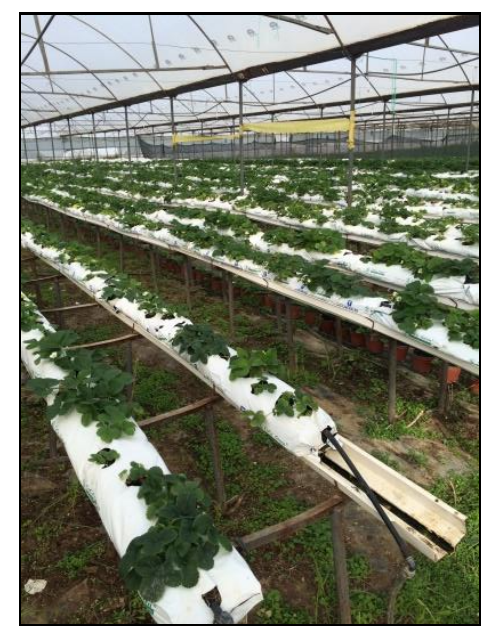

Figure 1. General view from exper
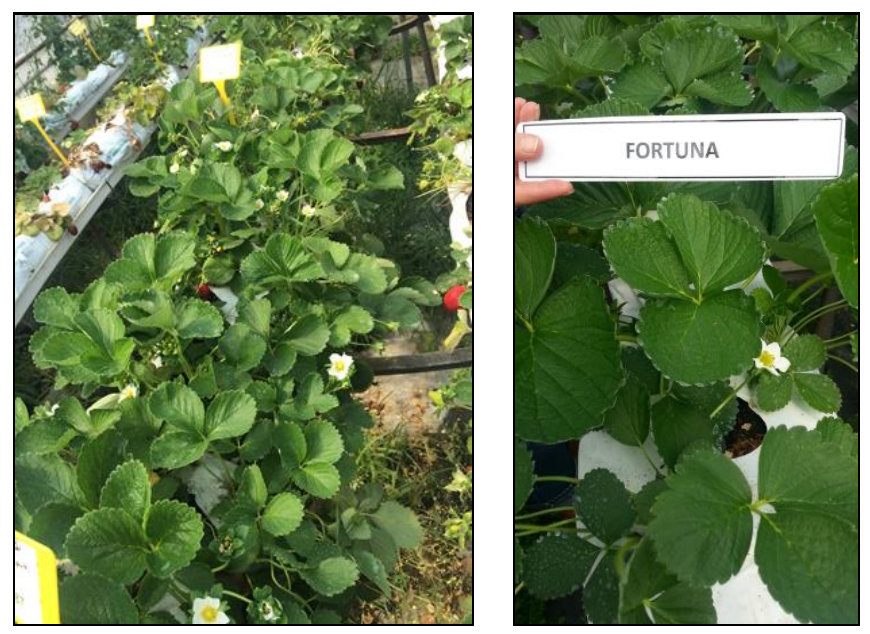

GB application (right)

\section{Fruit weight and yield}

The effects of GB concentrations, cultivars, GB concentration x cultivar interactions on fruit weight and yield under deficit irrigation condition are given in Table 3. As seen in Table 3, increasing GB concentrations from $0 \mathrm{mM}$ to $20 \mathrm{mM}$ induced fruit weight to increase. The highest fruit weight was determined at $20 \mathrm{mM} \mathrm{GB}$ application (13.49 g). In the case of fruit weight, there were no statistical differences between cultivars. Regarding interactions, the highest fruit weight was found at $20 \mathrm{mM}$ GB concentrations $(13.81 \mathrm{~g}$ and $13.17 \mathrm{~g})$, the lowest values were determined in control applications $(9.74 \mathrm{~g}$ and $8.31 \mathrm{~g}$ ) in all the tried cultivars.

In the case of fruit yield per plant, all tried GB treatments increased yield as compared to the control under deficit irrigation condition. Among the treatments, the highest fruit yield per plant was founded in $10 \mathrm{mM} \mathrm{GB}\left(359.00 \mathrm{~g} \cdot\right.$ plant $\left.^{-1}\right)$, followed by $20 \mathrm{mM}$ GB concentrations (301.33 g.plant $\left.{ }^{-1}\right)$. Fruit yield were found statistically different according to cultivars. The highest yield per plant was determined in Fortuna cultivar with $351.00 \mathrm{~g} \cdot$ plant $^{-1}$ under deficit irrigation conditions (Table 3). Regarding interaction between GB concentrations and cultivars, the highest fruit yield was founded in $10 \mathrm{mM}$ GB X Fortuna cultivar $\left(430.67 \mathrm{~g} \cdot\right.$ plant $\left.^{-1}\right)$ (Table 3).

Consequently, all tried GB concentrations increased fruit weight and yield as compared to control. In fact, fruit weight inclined by $26.29-49.50 \%$ and fruit yield by $17.17-39.59 \%$ at GB treatments as compared to control. These results were similar to the values reported by other authors (Makela et al., 1998; Rezaei et al., 2012; Rady et al., 2018). Makela et al. (1998) emphasized that $3.36 \mathrm{~kg} \cdot \mathrm{ha}^{-1} \mathrm{~GB}$ during mid flowering 
period increased fruit yield by 36 and $39 \%$, as compared to control in tomato plants under salt and heat stress conditions. Furthermore, Rezaei et al. (2012) reported that the $10 \mathrm{mM}$ exogenous glycinebetaine was the best treatment in terms of reproductive growth parameters on tomato plant grown under drought conditions. Rady et al. (2018) reported that GB treatments remarkably increased bulb yields of onion under $4.80 \mathrm{dS} \cdot \mathrm{m}^{-}$ ${ }^{1}$ salt stress. However, our results were in contrast to the findings of Meek et al. (2003), who pointed out that the yield components were not affected in drought stress in cotton plants by foliar GB applications. It can be said that differences on determined GB concentrations may be caused by differences in species, cultivar and application.

Table 3. Effects of different glycine betaine concentrations on fruit weight and yield at different strawberry cultivars grown under deficit irrigations

\begin{tabular}{|c|c|c|c|}
\hline \multirow{3}{*}{ Glycine Betaine Con. $(\mathrm{mM})$} & \multicolumn{2}{|c|}{ Cultivars } & \multirow{3}{*}{ Treatments } \\
\hline & Fortuna & Albion & \\
\hline & \multicolumn{2}{|c|}{ Fruit weight (g) } & \\
\hline 0 & $9.74 \mathrm{BC}^{*}$ & $8.31 \mathrm{C}$ & $9.02 \mathrm{c}^{*}$ \\
\hline 10 & $12.17 \mathrm{AB}$ & $10.61 \mathrm{BC}$ & $11.39 \mathrm{~b}$ \\
\hline 20 & $13.81 \mathrm{~A}$ & $13.17 \mathrm{~A}$ & $13.49 \mathrm{a}$ \\
\hline Cultivars & 11.90 & 10.69 & \\
\hline \multicolumn{4}{|c|}{ LSD $\% 5$ treatment: $2.490 ; \mathrm{LSD} \% 5$ cultivar: NS; LSD $\% 5$ treatmentx cultivar:2.512 } \\
\hline \multicolumn{4}{|c|}{ Yield $\left(g \cdot\right.$ plant $\left.^{-1}\right)$} \\
\hline 0 & $287.67 \mathrm{~B}$ & $226.67 \mathrm{~B}$ & 257.17 b \\
\hline 10 & $430.67 \mathrm{~A}$ & $287.33 \mathrm{~B}$ & $359.00 \mathrm{a}$ \\
\hline 20 & $334.67 \mathrm{AB}$ & $268.00 \mathrm{~B}$ & $301.33 \mathrm{ab}$ \\
\hline Cultivars & 351.00 a & 260.67 b & \\
\hline
\end{tabular}

*The comparison of the means of the cultivars is done within the same row and means of treatment in the same column and the interaction between all the values are significantly different $(P \leq 0.05)$ using LSD comparison test. The mean of treatment and cultivar are shown in lowercase letters while interactions are in uppercase.

$* * n=26$

\section{Total soluble solid (TSS), titratable acidity (TA) and firmness}

The effects of GB concentrations, cultivars, GB concentration x cultivar interactions on total soluble solid (TSS), titratable acidity (TA), and firmness under deficit irrigation condition are given in Table 4. As seen in Table 4, while the effects of strawberry cultivars on TSS, TA and firmness were found statistically different, GB concentrations was insignificant differences. As a matter of fact, the highest TSS value was determined in the Albion (7.39\%) and the highest TA was in the Fortuna $(0.78 \%)$ and the highest firmness was in the Fortuna cultivar $\left(0.57 \mathrm{~kg} \cdot \mathrm{cm}^{-2}\right)$ under deficit irrigation condition. Regarding the interaction between GB concentrations and cultivars, the highest TSS was founded in the Albion x Control (7.56\%) and Albion x $10 \mathrm{mM} \mathrm{GB} \mathrm{(7.36 \% ).} \mathrm{In}$ addition the highest TA value was determined in the Albion x $10 \mathrm{mM}$ GB interaction $(0.80 \%)$ (Table 4).

Consequently, exogenous GB applications did not affect to total soluble solid, titratable acidity, firmness whereas cultivars significantly affected these criteria. Between the cultivars, TSS was higher in the Albion, whereas TA and firmness were in the Fortuna under deficit irrigation condition. However, our results differed from those of YingYun et al. (2012) who reported that exogenous betaine significantly increased 
the photosynthetic pigments and soluble sugar content. This difference is thought to be caused by species, cultivar and growing conditions.

Table 4. Effects of different glycine betaine concentrations on total soluble solid (TSS), titratable acidity (TA) and firmness at different strawberry cultivars grown under deficit irrigations

\begin{tabular}{|c|c|c|c|}
\hline \multirow{3}{*}{ Glycine Betaine Con. (mM) } & \multicolumn{2}{|c|}{ Cultivars } & \multirow{3}{*}{ Treatments } \\
\hline & Fortuna & Albion & \\
\hline \multirow{2}{*}{\multicolumn{4}{|c|}{ TSS (\%) }} \\
\hline & & & \\
\hline 10 & $6.70 \mathrm{BC}$ & $7.36 \mathrm{~A}$ & 7.03 \\
\hline 20 & $6.36 \mathrm{C}$ & $7.23 \mathrm{AB}$ & 6.80 \\
\hline Cultivars & $6.54 \mathrm{~b}$ & $7.39 \mathrm{a}$ & \\
\hline \multicolumn{4}{|c|}{ LSD $\% 5$ treatment: NS; LSD $\% 5$ cultivar: $0.48 ;$ LSD $\% 5$ treatmentx cultivar:0.593 } \\
\hline \multicolumn{4}{|c|}{ TA $(\%$ citric acid $)$} \\
\hline 0 & $0.70 \mathrm{C}$ & $0.76 \mathrm{~B}$ & 0.73 \\
\hline 10 & $0.72 \mathrm{C}$ & $0.80 \mathrm{~A}$ & 0.76 \\
\hline 20 & $0.70 \mathrm{C}$ & $0.77 \mathrm{AB}$ & 0.74 \\
\hline Cultivars & $0.78 \mathrm{a}$ & $0.71 \mathrm{~b}$ & \\
\hline \multicolumn{4}{|c|}{ LSD $\% 5$ treatment:NS; LSD $\% 5$ cultivar:0.02; LSD $\% 5$ treatmentx cultivar:0.038 } \\
\hline \multicolumn{4}{|c|}{ Firmness $\left(\mathrm{kg} \cdot \mathrm{cm}^{-2}\right)$} \\
\hline 0 & $0.57 \mathrm{~A}$ & $0.45 \mathrm{~B}$ & 0.51 \\
\hline 10 & $0.56 \mathrm{~A}$ & $0.41 \mathrm{~B}$ & 0.49 \\
\hline 20 & $0.56 \mathrm{~A}$ & $0.43 \mathrm{~B}$ & 0.50 \\
\hline Cultivars & $0.57 \mathrm{a}$ & $0.43 \mathrm{~b}$ & \\
\hline $\mathrm{LSD} \% 5$ treatment:NS; LSD $\% 5$ cultive & $\mathrm{SD} \% 5$ treatı & & \\
\hline
\end{tabular}

*The comparison of the means of the cultivars is done within the same row and means of treatment in the same column and the interaction between all the values are significantly different $(P \leq 0.05)$ using LSD comparison test. The mean of treatment and cultivar are shown in lowercase letters while interactions are in uppercase.

$* * n=26$

\section{Colour}

The effects of GB concentrations, cultivars, GB concentration x cultivar interactions on $\mathrm{L}^{*}$, chroma, and hue $\left(\mathrm{h}^{\circ}\right)$ under deficit irrigation condition are given in Table 5. As seen in Table 5, statistical analysis showed that there were insignificant differences in terms of lightness $\left(\mathrm{L}^{*}\right)$ values according to cultivars and treatments. Regarding interactions, the highest lightness $\left(\mathrm{L}^{*}\right)$ value was founded in Fortuna x $10 \mathrm{mM}$ GB (34.38) (more brighter); the lowest $\mathrm{L}^{*}$ value was Albion x $10 \mathrm{mM}$ GB (29.57) (less brighter). In terms of chroma value, while the highest value was determined in $10 \mathrm{mM}$ GB (34.32), the lowest was in control treatment (32.21). In Table 5, on the basis of cultivars, the highest color intensity (chroma) value was found in the Fortuna cultivar (34.56) and the highest $\mathrm{h}^{\mathrm{o}}$ values were at 10 and $20 \mathrm{mM}$ GB concentrations. Indeed, the highest chroma and $\mathrm{h}^{\mathrm{o}}$ values were determined in the Fortuna and 10-20 mM GB treatments (light-colored).

Consequently, GB applications negatively affected fruit colour in terms of chroma and $h^{\circ}$ values as compared to control. In this concern, no literature was found regarding the effect of GB treatments on fruit colour in any horticultural plant. 
Table 5. Effects of different glycine betaine concentrations on fruit colour ( $L^{*}$, Chroma, $h^{o}$ ) at different strawberry cultivars grown under deficit irrigations

\begin{tabular}{|c|c|c|c|}
\hline \multirow{3}{*}{ Glycine Betaine Con. $(\mathrm{mM})$} & \multicolumn{2}{|c|}{ Cultivars } & \multirow{3}{*}{ Treatments } \\
\hline & Fortuna & Albion & \\
\hline & \multicolumn{2}{|c|}{$\mathbf{L}^{*}$} & \\
\hline 0 & $30.32 \mathrm{AB}^{*}$ & $32.58 \mathrm{AB}$ & 31.45 \\
\hline 10 & $34.38 \mathrm{~A}$ & $29.57 \mathrm{~B}$ & 31.97 \\
\hline 20 & $31.23 \mathrm{AB}$ & $31.59 \mathrm{AB}$ & 31.41 \\
\hline Cultivars & 31.98 & 31.25 & \\
\hline \multicolumn{4}{|c|}{ LSD $\% 5$ treatment:NS; LSD $\% 5$ cultivar: NS; LSD $\% 5$ treatmentx cultivar:4.46 } \\
\hline \multicolumn{4}{|c|}{$\begin{array}{ll} & \text { Chroma }\end{array}$} \\
\hline 0 & $32.28 \mathrm{BC}$ & $32.14 \mathrm{BC}$ & $32.21 \mathrm{~b}$ \\
\hline 10 & $34.89 \mathrm{AB}$ & $33.76 \mathrm{AB}$ & $34.32 \mathrm{a}$ \\
\hline 20 & $36.52 \mathrm{~A}$ & $30.37 \mathrm{C}$ & $33.29 \mathrm{ab}$ \\
\hline Cultivars & $34.56 \mathrm{a}$ & $31.99 \mathrm{~b}$ & \\
\hline \multicolumn{4}{|c|}{ LSD $\% 5$ treatment: $2.109 ; \mathrm{LSD} \% 5$ cultivar: $1.72 ; \mathrm{LSD} \% 5$ treatmentx cultivar: 2.983} \\
\hline \multicolumn{4}{|c|}{$\mathbf{h}^{\mathbf{0}}$} \\
\hline 0 & $29.86 \mathrm{C}$ & $35.11 \mathrm{BC}$ & $32.48 \mathrm{~b}^{*}$ \\
\hline 10 & $41.67 \mathrm{~A}$ & $37.44 \mathrm{AB}$ & $39.55 \mathrm{a}$ \\
\hline 20 & $37.44 \mathrm{AB}$ & $37.84 \mathrm{AB}$ & 37.64 a \\
\hline Cultivars & 36.80 & 36.32 & \\
\hline
\end{tabular}

*The comparison of the means of the cultivars is done within the same row and means of treatment in the same column and the interaction between all the values are significantly different $(\mathrm{P} \leq 0.05)$ using LSD comparison test. The mean of treatment and cultivar are shown in lowercase letters while interactions are in uppercase.

$* * \mathrm{n}=26$

\section{Ascorbic acid (AA) and total monomeric anthocyanins (TMA)}

The data on ascorbic acid and total monomeric anthocyanin (TMA) content determined were given in Table 6. As seen in Table 6, increasing GB concentrations from $0 \mathrm{mM}$ to 20 $\mathrm{mM}$ caused ascorbic acid contents to increase. As a matter of fact, the highest ascorbic acid (AA) content was founded at $20 \mathrm{mM} \mathrm{GB}$ application $\left(35.29 \mathrm{mg} \cdot 100 \mathrm{~g}^{-1} \mathrm{FW}\right.$ ), the lowest was in control $(24.79 \mathrm{mg} / 100 \mathrm{~g} \mathrm{FW})$. Furthermore, on the basis of cultivars, Albion strawberry cultivar $\left(34.17 \mathrm{mg} \cdot 100 \mathrm{~g}^{-1} \mathrm{FW}\right)$ was determined higher than the Fortuna strawberry cultivar $\left(27.91 \mathrm{mg} \cdot 100 \mathrm{~g}^{-1} \mathrm{FW}\right)$ in terms of AA. Interactions between cultivar and GB concentrations showed significant effects on AA. In general, Albion x 10-20 mM GB interactions gave the highest values (39.91 and $\left.37.53 \mathrm{mg} \cdot 100 \mathrm{~g}^{-1} \mathrm{FW}\right)$ (Table 6).

As seen in Table 6, statistical analysis showed that there were significant differences in terms of TMA contents according to cultivars and GB treatments. As a matter of fact, increasing GB concentrations from $0 \mathrm{mM}$ to $20 \mathrm{mM}$ caused TMA to decrease. While the highest TMA content was founded in control with $511.97 \mathrm{mg} \mathrm{Pg}-3 \mathrm{glk} \cdot \mathrm{kg}^{-1} \mathrm{FW}$; the lowest was at $20 \mathrm{mM} \mathrm{GB}$ treatment with $480.70 \mathrm{mg} \mathrm{Pg}-3 \mathrm{glk} \cdot \mathrm{kg}^{-1} \mathrm{FW}$. On the basis of cultivars examined for the TMA content the highest value was determined in the Fortuna cultivar (517.66 mg Pg-3 glk $\mathrm{kg}^{-1} \mathrm{FW}$ ). Interactions between cultivar and GB treatments showed significant effects on TMA. In general, the highest TMA values were obtained in control $\mathrm{x}$ Fortuna cultivar (544.23 mg Pg-3 glk $\cdot \mathrm{kg}^{-1} \mathrm{FW}$ ) (Table 6).

Consequently, increasing GB concentrations from $0 \mathrm{mM}$ to $20 \mathrm{mM}$ caused total anthocyanin content to decrease, whereas the ascorbic acid content increased. Similar results were obtained in previous studies (Karjalainen et al., 2002; Shams et al., 2016). In 
this regard, Karjalainen et al. (2002) indicated that foliar-applied glycine betaine (50 $\mathrm{mM})$ and benzothiadiazole ( $60 \mathrm{~g} / \mathrm{ha}$ ) at the young-seedling stage (3-4 leaf stage) enhanced the levels of several phenolic compounds in strawberry leaves under field condition. Remarkable increases were detected in the levels of ellagitannin, ellagic acid and gallic acid derivates, quercetin and kaempferol konjugates. Briefly, the authors suggest that exogenously applied BTH and glycine betaine may be used to increase the levels of protective and health-promoting compounds in strawberries. Likewise, Shams et al. (2016) tried four concentrations of GB $(0,5,10$, and $25 \mathrm{mM})$ and two levels of salinity $(0$ and 100 $\mathrm{mM}$ of $\mathrm{NaCl}$ ) in lettuce plants. Results showed that the $25 \mathrm{mM} \mathrm{GB}$ treatment increased dry matter and the content of total phenolics compared to the non-GB-treated plants under salt stress. Briefly, the authors suggested that exogenous GB treatments could ameliorate the tolerance of lettuce to salt stress by increasing the total antioxidants and total phenolics. Also, Khadouri (2015) noted the beneficial effects of GB application on biochemical and mineral content on cowpea plant.

Table 6. Effects of different glycine betaine concentrations on ascorbic acid (AA) and total monomeric anthocyanin content (TMA) at different strawberry cultivars grown under deficit irrigations

\begin{tabular}{|c|c|c|c|}
\hline \multirow{3}{*}{ Glycine Betaine Con. (mM) } & \multicolumn{2}{|c|}{ Cultivars } & \multirow{3}{*}{ Treatments } \\
\hline & Fortuna & Albion & \\
\hline & \multicolumn{2}{|c|}{ AA $\left(\mathrm{mg} \cdot 100 \mathrm{~g}^{-1} \mathrm{FW}\right)$} & \\
\hline 0 & $24.54 \mathrm{C}^{*}$ & $25.05 \mathrm{C}$ & $24.79 b^{*}$ \\
\hline 10 & $26.13 \mathrm{C}$ & $39.91 \mathrm{~A}$ & 33.02 a \\
\hline 20 & $33.06 \mathrm{~B}$ & $37.53 \mathrm{AB}$ & 35.29 a \\
\hline Cultivars & $27.91 \mathrm{~b}$ & 34.17 a & \\
\hline \multicolumn{4}{|c|}{ LSD $\% 5$ treatment: $4.75 ;$ LSD $\% 5$ cultivar: $3.87 ; \mathrm{LSD} \% 5$ treatmentx cultivar:6.711 } \\
\hline \multicolumn{4}{|c|}{ TMA $\left(\mathrm{mg} \cdot \mathrm{Pg}-3 \mathrm{glk} \cdot \mathrm{kg}^{-1} \mathrm{FW}\right)$} \\
\hline 0 & $544.23 \mathrm{~A}$ & $479.70 \mathrm{C}$ & 511.97 a \\
\hline 10 & $520.15 \mathrm{AB}$ & $465.16 \mathrm{C}$ & $492.65 \mathrm{ab}$ \\
\hline 20 & $488.62 \mathrm{BC}$ & $472.78 \mathrm{C}$ & $480.70 \mathrm{~b}$ \\
\hline Cultivars & 517.66 a & $472.54 \mathrm{~b}$ & \\
\hline$\underline{\mathrm{LSD}} \% 5$ treatment $23.58 ; \mathrm{LSD} \% 5$ & $25 ; \mathrm{LSD} \% 5 \mathrm{tr}$ & & \\
\hline
\end{tabular}

Ascorbic acid content (AA) was determined by HPLC method of Bozan et al.(1997). Values were expressed as $\mathrm{mg} / 100 \mathrm{~g}$ fresh weight basis (FW).

Total anthocyanin content (TAC) was determined by the $\mathrm{pH}$-differential method of Giusti and Wrolstad (2001). Values were expressed in $\mathrm{mg} \cdot \mathrm{Pg}-3 \mathrm{glk} \cdot \mathrm{kg}^{-1}$ by spectrophotometer.

*The comparison of the means of the cultivars is done within the same row and means of treatment in the same column and the interaction between all the values are significantly different $(P \leq 0.05)$ using LSD comparison test. The mean of treatment and cultivar are shown in lowercase letters while interactions are in uppercase.

$* *$ The results based on wet basis for fresh fruit.

$* * * n=26$

\section{Conclusion}

Considering the rise in global warming, environmental changes and water shortage will affect sustainable agriculture. Therefore, identification of resistant and tolerant cultivars to stress conditions are crucial for future breeding programs. Furthermore, it is very important to determine suitable agents and application concentrations of these agents under drought stress conditions. In this regard, glycine betaine is environmentally safe, non-toxic and water-soluble and can be practically applied on plants. 
In this study, we examined the various effects of glycine betaine concentrations on plant morpho-physiological features, fruit physical and some biochemical features in two different soilless grown strawberry cultivars under deficit irrigation conditions. Our results showed that exogenous GB treatments induced plant growth and development, fruit yield as compared to untreated GB under stress condition. The best GB concentration was $10 \mathrm{mM}$ in terms of fruit weight and yield. Fruit colour was affected negatively by GB concentrations. It can be said that the most important result was that increasing GB concentrations from $0 \mathrm{mM}$ to $20 \mathrm{mM}$ caused total anthocyanin content to decrease, whereas the ascorbic acid content increased. Furthermore, regarding cultivars, Fortuna was the best cultivar in terms of yield, titratable acidity, firmness and total anthocyanin, whereas Albion was the best cultivar in terms of total soluble solid and ascorbic acid content under deficit irrigation condions in soilless strawberry cultivation.

Acknowledgements. The author would like to acknowledge 2K VEG I.C. Foundation for supporting our study during the 2015-2016 production season and M. CIKER and B. TANRIVERDI for their assistance and Akdeniz University Food Safety and Agricultural Research Center for biochemical analysis.

\section{REFERENCES}

[1] Adak, N. (2009): Effects of different growing media on the yield and quality of soilless grown strawberries. - PhD thesis, Akdeniz University, Turkey.

[2] Adak, N., Tozlu, I., Gubbuk, H. (2018a): Influence of different soilless substrates to morphophysiological characteristics and yield relations in strawberries. - ErwerbsObstbau 60: 341-348.

[3] Adak, N., Gubbuk, H., Tetik, N. (2018b): Yield, quality and biochemical properties of various strawberry cultivars under water stress. - J. Sci. Food Agric. 98: 304-311.

[4] Ahmad, F., Aziz, T., Maqsood, M. A., Tahir, M. A., Kanwal, S. (2007): Effect of silicon application on wheat (Triticum aestivum L.) growth under water deficiency stress. Emir. J. Food Agric. 19: 01-07.

[5] AOAC. (1980): Official methods of analysis. - 13th ed. Association of Official Analytical Chemists, Washington, DC, USA. Section 31.034.

[6] Aras, S., Esitken, A. (2013): Effects of antifreeze proteins and glycine betaine on strawberry plants for resistance to cold temperature. - International Conference on Agriculture and Biotechnology IPCBEE vol.60. IACSIT Press, Singapore DOI: 10.7763/IPCBEE. V60. 21: 107-111.

[7] Armin, M., Reza Miri, H. (2014): Effects of glycine betaine application on quantitative and qualitative yield of cumin under irrigated and rain-fed cultivation. - Journal of Essential Oil Bearing Plants 17(4): 708-716.

[8] Bakhsh, A., Hussain, T. (2015): Engineering crop plants against abiotic stress: Current achievements and prospects. - Emir. J. Food Agric. 27(1): 24-39.

[9] Barreales, D., Malheiro, R., Pereira, J. A., Verdial, J., Bento, A., Casquero, P. A., Ribeiro, A. C. (2019): Effects of irrigation and collection period on grapevine leaf (Vitis vinifera L. var. Touriga Nacional): Evaluation of the phytochemical composition and antioxidant properties. - Scientia Horticulturae 245: 74-81.

[10] Bozan, B., Tunalier, Z., Kosar, M., Altıntas, A., Baser, K. H. C. (1996): Quantitative analysis of vitamin $\mathrm{C}$ in rose hip products collected from local markets in Turkey. - Proc XI Symposium Plant Originated Crude Drugs, Ankara, 22-24 May. pp. 258-266.

[11] Centofanti, T., Banuelos, G. S., Wallis, C. M., Ayars, J. E. (2017): Deficit irrigation strategies and their impact on yield and nutritional quality of pomegranate fruit. - Fruits 72(1): 47-54. 
[12] Cramer, G. R., Ergül, A., Grimplet, J., Tillett, R. L., Tattersall, E. A., Bohlman, M. C., Vincent, D., Sonderegger, J., Evans, J., Osborne, C., Quilici, D., Schlauch, K. A., Schooley, D. A., Cushman, J. C. (2007): Water and salinity stress in grapevines: early and late changes in transcript and metabolite profiles. - Funct Integr Genomics 7: 111134.

[13] Dawood, M. G. (2016): Influence of osmoregulators on plant tolerance to water stress. Sci. Agri 13(1): 42-58.

[14] Denaxa, N. K., Roussos, P. A., Damvakaris, T., Stournaras, V. (2012): Comparative effects of exogenous glycine betaine, kaolin clay particles and ambiol on photosynthesis, leaf sclerophylly indexes and heat load of olive cv. Chondrolia Chalkidikis under drought. - Sci. Hort. 137: 87-94.

[15] Diaz-Zorita, M., Fernandez-Canigia, M. V., Grosso, G. A. (2001): Applications of foliar fertilizers containing glycine betaine improve wheat yields. - J. Agron. Crop Sci. 186: 209-215.

[16] Dutta, T., Neelapu, N. R. R., Wani, S. H., Challa, S. (2018): Chapter 11- Compatible solute engineering of crop plants for improved tolerance toward abiotic stresses. Biochemical, Physiological and Molecular Avenues for Combating Abiotic Stress Tolerance in Plants: 221-254. https://doi.org/10.1016/B978-0-12-813066-7.00012-7.

[17] FAO. (2018): FAOSTAT, Statistical Database. - Available: http://faostat.fao.org/site/567/DesktopDefault.aspx?PageID=567\#ancor [6 March 2018].

[18] Fereres, E., Soriano, M. A. (2007): Deficit irrigation for reducing agricultural water use. Journal of Experimental Botany 58(2): 147-159.

[19] Giusti, M. M., Wrolstad, R. E. (2001): Characterization and measurement of anthocyanins by UV-visible spectroscopy. - In: Wrolstad, R. E., Wiley, J. (eds.) Current Protocols in Food Analytical Chemistry. New York, Unit F1.2.1-Unit F1.2.13.

[20] Harinasut, P., Tsutsui, K., Takabe, T., Nomura, M., Takabe, T., Kishitani, S. (1996): Exogenous glycine betaine accumulation and increased salt tolerance in rice seedlings. Biosci. Biotechnol. Biochem. 60: 366-368.

[21] Karjalainen, R., Lehtinen, A., Keinanen, M., Julkunen-Tiitto, R., Hietaniemi, V., Pihlava, J. M., Tiilikkala, K., Jokinen, K. (2002): Benzothiadiazole and glycinebetaine treatments enhance phenolic compound production in strawberry. - Acta Hort. 567: 353-356.

[22] Khadouri, H. K. (2015): Effects of glycine betaine on plant growth and performance of Alfalfa (Medicago Sativa L.) \& Cowpea (Vigna Unguiculata L. Walp.) within water deficit conditions. - United Arab Emirates University College of Food and Agriculture Department of Aridland Agriculture, MSc Thesis, pp 87.

[23] Lang, F. (2007): Mechanisms and significance of cell volume regulation. - J. Am. Coll. Nutr. 26 (5 Suppl): 613-623.

[24] Makela, P., Jokinen, K., Kontturi, M., Peltonen-Sainio, P., Pehu, E., Somersalo, S. (1998): Foliar application of glycine betaine- a novel product from sugar beet as an approach to increase tomato yield. - Ind. Crops and Prod. 7: 139-148.

[25] Makela, P. (2004): Agro-industrial uses of glycinebetaine. - Sugar Tech 6(4): 207-212.

[26] Meek, C., Oosterhuis, D., Gorham, J. (2003): Does foliar-applied glycine betaine affect endogenous betaine levels and yield in cotton? - Crop Management. doi 10.1094/CM2003-0804-02-RS.

[27] Mickelbart, M. V., Chapman, P., Collier-Christian, L. (2006): Endogenous levels and exogenous application of glycinebetaine to grapevines. - Sci. Hort. 111: 7-16.

[28] Muhammad, I., Ambreen, A., Nabeela, K. (2006): Four foliar application of glycine betaine did not alleviate advers effects of salt stress on growth of sunflower. - Pak. J. Bot. 38: 1561-1570.

[29] Osakabe, Y., Osakabe, K., Shinozaki, K., Tran, L. S. (2014): Response of plants to water stress. - Front. Plant Sci. 5: 1-8. 
[30] Osman, H. S., Salim, B. B. M. (2016): Influence of exogenous application of some phytoprotectants on growth, yield and pod quality of snap bean under $\mathrm{NaCl}$ salinity. Ann. Agric. Sci. 61: 1-13.

[31] Oukarroum, A., El-Madidi, S., Strasser, R. J. (2012): Exogenous glycine betaine and proline play a protective role in heat-stressed barley leaves (Hordeum vulgare L.): a chlorophyll a fluorescence study. - Plant Biosystems 146(4): 1037-1043.

[32] Park, E. J., Jeknic, Z., Chen, T. H. H. (2006): Exogenous application of glycine betaine increases chilling tolerance in tomato plants. - Plant Cell Physiol. 47(6): 706-714.

[33] Rady, M. O. A., Semida, W. M., El-Mageed, T. A. A., Hemida, K. A., Rady, M. M. (2018): Up-regulation of antioxidative defense systems by glycine betaine foliar application in onion plants confer tolerance to salinity stress. - Sci. Hort. 240: 614-622.

[34] Rajashekar, C. B., Zhou, H., Marcum, K. B., Prakash, O. (1999): Glycine betaine accumulation and induction of cold tolerance in strawberry (Fragaria $\mathrm{X}$ ananassa Duch.) plants. - Plant Sci. 148: 175-183.

[35] Rezaei, M. A., Jokar, I., Ghorbanli, M., Kaviani, B., Kharabian-Masouleh, A. (2012): Morpho-physiological improving effects of exogenous glycine betaine on tomato (Lycopersicum esculentum Mill.) cv. PS under drought stress conditions. - Plant Omics 5(2): 79-86.

[36] Selcuk, N., Erkan, M. (2015): Changes in phenolic compounds and antioxidant activity of sour-sweet pomegranates cv. Hicaznar during long-term storage under modified atmosphere packaging. - Postharvest Biol. Tech. 109: 30-39.

[37] Shams, M., Yildirim, E., Ekinci, M., Turan, M., Dursun, A., Parlakova, F., Kul, R. (2016): Exogenously applied glycine betaine regulates some chemical characteristics and antioxidative defence systems in lettuce under salt stress. - Hortic. Environ. Biotechnol. 57(3): 225-231.

[38] Shi, H., Jiang, C., Ye, T., Chan, Z. (2014): Comparative Physiological, Metabolomic, And Transcriptomic Analyses Reveal Mechanisms Of Improved Abiotic Stress Resistance In Bermudagrass [Cynodon Dactylon (L). Pers.] By Exogenous Melatonin. - J. EXP. BOT. 66(3): 681-694.

[39] Souza, R. P., Machado, E. C., Silva, J. A. B., Lagoa, A. M. M. A., Silveira, J. A. G. (2004): Photosynthetic gas exchange, chlorophyll fluorescence and some associated metabolic changes in cowpea (Vigna unguiculata) during water stress and recovery. Environ. Exp. Bot. 51: 45-56.

[40] Tunc, T., Sahin, U., Evren, S., Dasci, E., Guney, E., Aslantas, R. (2019): The deficit irrigation productivity and economy in strawberry in the different drip irrigation practices in a high plain with semi-arid climate. - Sci. Hort. 245: 47-56.

[41] TURKSTAT. (2017): Turkish Statistical Institue. - http://www.tuik.gov.tr/ PreTablo.do?alt_id=1001. Accessed 28 Feb 2017.

[42] Wani, S. H., Singh, N. B., Haribhushan, A., Mir, J. I. (2013): Compatible Solute Engineering in Plants for Abiotic Stress Tolerance - Role of Glycine Betaine. - Current Genomics 14(3): 157-165.

[43] Wyn Jones, R. G., Storey, R. (1981): Betaines. - In: Paleg, L. G., Aspinal, D. (eds.) The Physiology and Biochemistry of Drought Resistance in Plants. New York, pp. 171-204.

[44] Yang, X., Lu, C. (2005): Photosynthesis is improved by exogenous glycine betaine in salt-stressed maize plants. - Physiol. Plant. 124: 343-352.

[45] Yildirim, E., Ekinci, M., Turan, M., Dursun, A., Kul, R., Parlakova, F. (2015): Roles of glycine betaine in mitigating deleterious effect of salt stress on lettuce (Lactuca sativa L.). - Archives of Agronomy and Soil Science 61(12): 1673-1689.

[46] YingYun, H., DanHua, Z., HongZhang, L., DeKun, D. (2012): Effects of exogenous glycine betaine on the physiological indexes of soybean seedlings under $\mathrm{NaCl}$ stress. Acta Agriculturae Zhejiangensis 24(1): 12-16.

[47] Youssef, S. M., Elhady, S. A. A., Aref, R. M., Riad, G. S. (2018): Salicylic acid attenuates the adverse effects of salinity on growth and yield and enhances peroxidase 
isozymes expression more competently than proline and glycine betaine in cucumber plants. - Gesunde Pflanzen 70(2): 75-90.

[48] Zamani, M. M., Rabiei, V., Nejatian, M. A. (2013): Effect of proline and glycine betaine application on some physiological characteristics in grapevine under drought stress. Iranian Journal of Horticultural Science 43(4): 393-401.

[49] Zamani, M. M., Rabiei, V., Nejatian, M. A., Taheri, M. (2014): Effect of exogenous application of proline and glycine betaine on biochemical alterations in grapevine under drought stress. - Journal of Crops Improvement 16(2): 247-258.

[50] Zhang, H. Y., Wang, Y. N., Han, T., Li, L. P., Xu, L. (2008): Effect of exogenous glycine betaine on chilling injury and chilling-resistance parameters in cucumber fruits stored at low temperature. - Sci. Agric. Sin. 41(8): 2407-2412.

[51] Zhu, J. K. (2016): Abiotic stress signaling and responses in plants. - Cell 167: 313-324.

[52] Zlatev, Z., Lidon, F. C. (2012): An overview on drought induced changes in plant growth, water relations and photosynthesis. - Emir. J. Food Agric. 24(1): 57-72. 